\title{
3D Microstructural Characterization of Ni/YSZ Electrodes Exposed to 1 Year of Electrolysis Testing
}

Trini, M.; Jørgensen, P. S.; Hauch, A.; Bentzen, J. J.; Hendriksen, P. V.; Chen, M.

Published in:

Journal of the Electrochemical Society

Link to article, DOI:

10.1149/2.1281902jes

10.1149/2.1281902jes

Publication date:

2019

Document Version

Peer reviewed version

Link back to DTU Orbit

Citation (APA):

Trini, M., Jørgensen, P. S., Hauch, A., Bentzen, J. J., Hendriksen, P. V., \& Chen, M. (2019). 3D Microstructural Characterization of Ni/YSZ Electrodes Exposed to 1 Year of Electrolysis Testing. Journal of the Electrochemical Society, 166(2), F158-F167. https://doi.org/10.1149/2.1281902jes, https://doi.org/10.1149/2.1281902jes

\section{General rights}

Copyright and moral rights for the publications made accessible in the public portal are retained by the authors and/or other copyright owners and it is a condition of accessing publications that users recognise and abide by the legal requirements associated with these rights.

- Users may download and print one copy of any publication from the public portal for the purpose of private study or research.

- You may not further distribute the material or use it for any profit-making activity or commercial gain

- You may freely distribute the URL identifying the publication in the public portal 


\title{
3D Microstructural Characterization of Ni/YSZ Electrodes Exposed to 1 Year of
}

\section{Electrolysis Testing}

\author{
M. Trinia ${ }^{a, z}$, P. S. Jørgensen ${ }^{\mathrm{a}}$, A. Hauch ${ }^{\mathrm{a}}$, J. J. Bentzen ${ }^{\mathrm{a}}$, P. V. Hendriksen ${ }^{\mathrm{a}}$, M. Chen ${ }^{\mathrm{a}, \mathrm{z}}$ \\ ${ }^{a}$ Department of Energy Conversion and Storage, Technical University of Denmark, \\ Frederiksborgvej 399, 4000 Roskilde, Denmark \\ ${ }^{z}$ Corresponding Author E-mail Address: mtri@dtu.dk, minc@dtu.dk
}

\begin{abstract}
Long-term operation strongly affects the microstructure of Ni/YSZ cermets used in state of the art fuel electrodes for solid oxide cells. The microstructural changes are considered to heavily affect the cell degradation. In this paper, the characterization of the Ni/YSZ electrode of a solid oxide electrolysis cell tested as part of a stack tested for 1 year was performed through focused ion beam-scanning electron microscopy and energy dispersive X-ray spectroscopy. A reference cell and two locations of interest in the tested cell were selected: one at the steam inlet side and the other at the outlet. Considerable microstructural changes were observed in the tested cell compared to the reference cell and between the inlet and outlet side. A decrease in $\mathrm{Ni}$ (from $30 \%$ in the reference cell to $24 \%$ in the tested cell), and in percolating triple phase boundaries length (from $2.83 \mu \mathrm{m} / \mu \mathrm{m}^{3}$ in the reference cell to $0.76 \mu \mathrm{m} / \mu \mathrm{m}^{3}$ in the tested cell) was observed in the active fuel electrode. Based on the results of this work and previous studies we hypothesize that the degradation trend between different operating conditions at the inlet and outlet of the cell is related to the current redistribution inside the cell.
\end{abstract}

This work is an extension of the work presented at the 15th International Symposium on Solid Oxide Fuel Cells (Hollywood, Florida, USA July 23 - 28, 2017) with the title "Microstructural Characterization of Ni/YSZ Electrodes in a Solid Oxide Electrolysis Stack Tested for 9000 Hours" (published on ECS Transactions, 78 [1] 3049-3064 (2017)). 


\section{Introduction}

The increased share of intermittent renewable energy in future green energy scenario raises the need for managing the energy production/energy demand mismatch. In this regard, developing effective means of converting and storing the electrical energy surplus generated by overproduction peaks is crucial for overall system economy and security of supply. The role of devices capable of efficiently converting electrical energy into a storable medium (e.g. hydrogen or carbon-based synthetic fuels) are become important in this context. For this purpose, solid oxide cells (SOCs) represent an interesting technology [1,2] since the same cell can be operated either in fuel cell mode as a solid oxide fuel cell (SOFC) or in electrolysis mode as a solid oxide electrolysis cell (SOEC) [3]. This characteristic makes it possible to use the same device for both electrical energy production and storage depending on the specific need.

Operational life spans of several years are required to make SOCs systems economically competitive on the market and long-term stability has to be guaranteed [4-8]. Hence, the systems, stacks, and cells and their individual components (such as manifolds, interconnects, electrodes etc.) must be reliable, robust and durable $[3,5]$. Relating the specific cell operation conditions with the degradation processes of the cell material and microstructures has been the objective of many studies [8-18]. This field of research aims to ensure and improve the long-term durability of the individual cells in a stack. Microstructural changes have been seen to affect all the components inside the cells and are considered one of the main causes of performance degradation $[3,8,11-18]$. Furthermore, additional studies have been performed with the aim of relating the specific microstructure changes with the decrease in electrochemical performance [e.g. 7, 8, 11].

Several degradation mechanisms in SOECs have been proposed in the last years $[3,7,8,10,11]$. Specifically, several studies were performed to investigate the effects of temperature, gas composition and current density [7, 11-13]. In order to compare the microstructure of different cells, ideally several complementary characterization techniques have to be applied on the same sample to obtain a proper description of the specific phenomenon observed. Concerning the changes in the materials composition and microstructure, scanning electron microcopy (SEM) and energy dispersive X-ray spectroscopy (EDS) are useful techniques [3]. To obtain a full microstructural characterization of the electrode structures, focused ion beam-scanning electron 
microscopy (FIB-SEM) technique has been extensively used [19-25]. The microstructural details that can be extracted from 3D tomographic reconstructions such as particles size distribution [26] and triple phase boundary (TPB) length [19-21, 25] provide quantification of microstructural features of the complex cermet structure. These parameters can complement and support the interpretation of electrochemical performance and durability data. Combining complete microstructural and electrochemical characterization can enable the description and quantification of specific degradation mechanisms occurring in the cell.

An attempt to relate electrochemical and microstructural degradation in SOECs was made by Hauch et al. [8] on cells tested for more than 1500 hours. It emerged that the Ni/YSZ electrode was the main source of performance degradation and $\mathrm{Ni}$ coarsening was one of the main mechanisms contributing to the decrease of active TPB sites for electrochemical reactions [27]. A qualitative post-mortem analysis was performed by Chen et al. [11] on SOECs tested up to 1500 hours, the authors showed the influence of temperature and current density on the Ni/YSZ electrode microstructure. It was observed that higher temperature and current density cause significant loss in percolation in the active fuel electrode. Recently, a microstructural investigation on long-term (i.e. 1000 hours) tested SOEC was reported by Hauch et al. [8]. By combining SEM and electrochemical impedance spectroscopy (EIS) measurements, the authors proposed an optimized fuel electrode microstructure capable of tolerating high $\mathrm{p}\left(\mathrm{H}_{2} \mathrm{O}\right)$ and current density with a low enough fuel electrode overpotential to make the SOC last for more than 5 years potentially. Few studies have investigated microstructural characterization of SOEC tested for longer than a few thousands hours. Tietz et al. [10] carried out a qualitative metallographic analysis of a 9000 hours tested SOEC by means of SEM images. For that specific cell, the main microstructural degradation was observed in the electrolyte while the Ni-YSZ electrode did not seem to be significantly affected by operation. In this context, a systematic quantification based on 3D tomographic reconstructions of SOECs tested for several thousands of hours is missing.

Among several degradation mechanisms observed in Ni-YSZ electrodes Ni agglomeration and coarsening is considered one of the main causes of performance loss for solid oxide cells [13, 28]. Many studies have been focusing on the Ni coarsening effect in the last years and it has been found that the particles growth is faster during the first hours $(0-1000 \mathrm{~h})$ of the test [13]. Much attention has been paid to microstructural changes in 
the Ni phase, indeed, and at typical cell operating conditions, the YSZ can be considered a stable scaffold wherein Ni re-distributes and increases in particles size. Tanasini et al. [28] observed this behavior through the analysis of SEM images. To the best of the authors' knowledge, only few studies addressed quantitative microstructural characterization of Ni/YSZ electrode of SOEC tested as part of a stack $[7,29,30]$ and a quantitative assessment of $\mathrm{Ni}$ coarsening for several thousands of hours of operation under technologically relevant conditions is still missing up to now.

In addition, only few examples of microstructural characterization of cells tested as part of a long-term tested SOC stack can be found in the literature. Faes et al. [13] tested several stacks for a maximum of 1900 hours in fuel cell mode and characterized the microstructure of Ni/YSZ electrodes by means of SEM micrographs. Rinaldi et al. [30] tested a short SOEC stack for 10,700 hours and then analyzed the microstructural degradation of each layer, the nickel depletion in the innermost region of the active fuel electrode was observed. Brisse et al. [31] tested the cell characterized in this work as part of a stack for $\sim 9000$ hours in technologically relevant operating conditions at the European Institute for Energy Research (EIfER). A preliminary microstructural characterization of the same cell was reported by our group [29] with the aim of investigating the microstructural degradation and we highlighted the differences between 2D and 3D quantification of the same electrode microstructure.

Quantifying microstructural changes of SOC is important for understanding the degradation processes occurring at the micrometer scale. With the aim of providing a detailed characterization of the microstructure; we combine here 3D tomographic reconstructions with EDS. The 3D characterization performed on FIB-SEM data provides detailed information on the network properties defining, not only the particles size, but also the quality of the connections. However, only small volumes can be analyzed with this technique and, in this regard, EDS maps provide important additional information of large areas of the cell. Two locations exposed to different local operating conditions (i.e. gas composition, current density, and temperature) inside the same cell were chosen for analysis: at the steam inlet and outlet. The microstructures of the two regions analyzed were compared with a reference cell exposed to reduction only and no long-term operation. Ni re-distribution was detected and changes in TPB and surface area of the three phases (i.e. Ni, YSZ and pores) were quantified. 
Moreover, hypotheses are proposed to explain the difference observed between the two locations in the longterm tested cell (inlet and outlet).

\section{Experimental}

111

One of 25 identical SOEC cells from a stack produced by Topsoe Fuel Cell A/S (Cell number 17 counting from top of the stack) is analyzed in the present work. The cells have a Ni/3YSZ support ( $300 \mu \mathrm{m}$ thickness) and a Ni/8YSZ fuel electrode ( $15 \mu \mathrm{m}$ thickness), a $8 \mathrm{YSZ}$ electrolyte, a CGO $\left(\mathrm{Ce}_{1-\mathrm{x}} \mathrm{Gd}_{\mathrm{x}} \mathrm{O}_{2-\mathrm{x} / 2}\right)$ barrier layer, and a CGO/LSCF $\left((\mathrm{La}, \mathrm{Sr})(\mathrm{Co}, \mathrm{Fe}) \mathrm{O}_{3-\delta}\right)$ oxygen electrode. On the top of the oxygen electrode a current collector layer is applied. The cells have an active area of $87.7 \mathrm{~cm}^{2}$ and are stacked in between coated Crofer interconnects [31].

\section{$\underline{\text { Testing and sample preparation }}$}

The long-term electrolysis testing of the stack analyzed in this work was performed at the EIFER. Essential parameters used for the operation are summarized in Table 1. Additional details about the test and stack performance can be found elsewhere [31]. The reference cell used in this work was a cell from the same production batch of the 25 cells in the stack. The reference cell was reduced at $750^{\circ} \mathrm{C}$ for 4 hours in moisturized $10 \% \mathrm{H}_{2}$ in $\mathrm{N}_{2}\left(10 \% \mathrm{H}_{2}, 90 \% \mathrm{~N}_{2}\right)$ and not tested further. The Ni/YSZ electrode of the reference cell was utilized for comparison with the tested cell.

\section{D Characterization}

After the test, part of the stack (Cells 11-25) was embedded in epoxy resin and then sectioned for further analysis. A sketch of the stack top view with relative sectioning is shown in Figure 1 a). A Zeiss XB1540 Crossbeam microscope was used for data collection by FIB serial sectioning on the reference cell and the two locations of interest on the long-term tested cell: the fuel inlet and outlet side. For the sake of simplicity, the three locations investigated will henceforth be defined as reference, inlet, and outlet, respectively. Cross sections of the same cell were analyzed in a previous work [29] to compare 1D and 3D microstructural characterization and to quantify degradation between the reference and the tested cell at the micrometer scale. Three-dimensional characterization was previously performed only for the reference and the inlet part of the 
tested cell [29]. Here, a more complete view of the aged cell is presented by adding the outlet dataset.

134 Furthermore, EDS analysis was performed on the regions of interest to estimate the chemical composition in different locations of the cells. The regions used for FIB-SEM characterization and EDS analysis are illustrated in Figure 1 b) and c) on the top of a SEM image of the reference cell showing the Ni/YSZ electrode and part of the YSZ electrolyte. The yellow box in Figure $1 \mathrm{~b}$ ) highlights the innermost $8 \mu \mathrm{m}$ of the active fuel electrode extracted from FIB-SEM dataset and used for the computation of microstructural parameters. Figure $1 \mathrm{c}$ ) illustrates the areas used for acquiring EDS data, smaller areas of $25 \times 3 \mu \mathrm{m}^{2}$ and $25 \mathrm{x} 10 \mu \mathrm{m}^{2}$ were also used for the fuel electrode and support layer, respectively. Figure 1d) shows a schematic drawing of the electrolyte $(\sim 5 \mu \mathrm{m})$, the active fuel electrode $(\sim 15 \mu \mathrm{m})$, and part of the support layer (overall thickness $\sim 300 \mu \mathrm{m})$ defined with dashed lines since only partially interested by the analysis. The direction of the FIB milling front is illustrated in Figure 1d together with the direction and width of the line scan recorded for the EDS analysis.

Due to slightly different microscope set-ups for the three samples analyzed, three different voxel sizes were obtained: $25 \times 25 \times 40.80 \mathrm{~nm}^{3}$ for the reference, $25 \times 25 \times 35.60 \mathrm{~nm}^{3}$ at the inlet and $25.53 \times 25.53 \times 37.79$ $\mathrm{nm}^{3}$ at the outlet of the tested cell. In order to analyze the same volume size (approximately $12.5 \times 8 \times 20 \mu m^{3}$ ) in each sample, three sub-volumes were selected: $501 \times 321$ x 490 pixels for the reference cell, $501 \times 321 \times$ 564 pixels for the inlet and $491 \times 314$ x 531 pixels for the outlet. With the aim of analyzing the innermost part of the active fuel electrode the dataset used for the computation of microstructural parameters starts, for each volume, $\sim 3 \mu \mathrm{m}$ away from the electrode-electrolyte interface and extends $\sim 8 \mu \mathrm{m}$ towards the support layer. The FIB milling front along the electrolyte is perpendicular to the electrode-electrolyte interface [32] (Figure 1); $35 \mathrm{~nm}$ are milled away, a picture of the support/electrode/electrolyte cross section is obtained, and next another $35 \mathrm{~nm}$ is milled away, and so forth, effectively collecting pictures of the cross section moving in the direction parallel to the electrode-electrolyte interface. Two sets of images (i.e. obtained from Inlens and SE2 detectors) were recorded for each sample and used for post-processing and segmentation as described elsewhere [32].

Once the segmented volumes were obtained, several analyses were performed on the inner fuel electrode subvolumes in order to compare the microstructure of the three locations investigated. The phase fraction of each 
phase in the region of interest was calculated by dividing the overall volume of a single phase by the total volume analyzed. The continuous PSD was computed as described earlier [26, 29, 32]. This method consists in evaluating, for each 2D section of the 3D reconstructions, the largest circle that fits the particle and extending that circle to a 3D sphere. The continuous PSD distribution is obtained by calculating the distribution of the largest spheres that can fit inside each part of the structure. Moreover, the total and percolating TPBs were also determined [22]. For what concerns the percolating sites, not only their total amount was determined but also the networking quality through the characteristic pathway diameter [32]. In addition, the tortuosity factor of the $\mathrm{Ni}$ and pore phase along the three directions of the volumes was determined using the program TauFactor [33].

\section{Energy Dispersive X-ray Spectroscopy (EDS)}

In addition to the 3D microstructural characterization, compositional information was obtained for the locations of interest by EDS. A field emission gun scanning electron microscope (Carl Zeiss Supra 35) equipped with an energy dispersive X-ray detector (Thermo Electron Corporation - NORAN System SIX) was used for the investigation. The EDS analyses were performed both as X-ray mapping, wide line scans, and as area analysis on polished carbon coated cross section surfaces. The applied acceleration voltage of $15 \mathrm{kV}$ resulted in an interaction volume of $\sim 1 \mu \mathrm{m}^{3}$. Cell number 17 in the stack was analyzed in the region close to a contact point between the cell and the interconnect. EDS data from $25 \times 3 \mu \mathrm{m}^{2}$ and $50 \times 3 \mu \mathrm{m}^{2}$ areas were recorded with NSS software using Proza (Phi-Rho-Z) correction, the data were then used to calculate the Ni/(Zr $+\mathrm{Y})$ atom ratio close to the electrode-electrolyte interface. In a larger area of the support layer, EDS data from $25 \times$ (3 to 10$) \mu \mathrm{m}^{2}$ and $50 \times(3$ to 20$) \mu \mathrm{m}^{2}$ areas were used to calculate the $\mathrm{Ni} /(\mathrm{Zr}+\mathrm{Y})$ atomic ratios. The regions used for the EDS analysis is illustrated if Figure $1 \mathrm{c}$ ). The counting statistic error for each measurement was estimated to be less than $1 \%$. In addition, $50 \mu \mathrm{m}$ wide EDS line scans (50 points per line) perpendicular to the electrode-electrolyte interface were recorded for the three locations of interest (Figure 1). The measurement of each line scan started 4-5 $\mu \mathrm{m}$ inside the electrolyte and extended into the support layer covering an overall length of $\sim 38 \mu \mathrm{m}$. Acquisition times of 75 seconds per spectrum was used for the line scans obtaining 30,000 nickel counts and a background of $\sim 2,500$ counts. 


\section{Results}

A 3D rendering of three sub-volumes extracted from the investigated geometries is shown in Figure 2. The dimension of each sub-domain is $\sim 8 \times 8 \times 8 \mu \mathrm{m}^{3}$ and the three phases of interest are represented as follows: Ni particles are red, YSZ scaffold is gray and pores are transparent. Part of the electrolyte is also introduced in the 3D reconstructions of Figure 2. Qualitative microstructural changes in the Ni phase can be identified clearly between the reference and both locations analyzed for the tested cell by simple visual inspection of the three cubes in Figure 2. The results of the 3D microstructural characterization performed on the three regions are presented in further detail in Table 2.

The central $8 \mu \mathrm{m}$ of the Ni/YSZ active electrode were analyzed starting $\sim 3 \mu \mathrm{m}$ away from the electrolyteelectrode interface and stopping $\sim 1 \mu \mathrm{m}$ before the interface between the active electrode and the support layer. Table 2 summarizes microstructural parameters quantified on each of the volumes investigated.

\section{Overall phase fractions of the fuel electrode:}

The first parameter discussed is the phase fraction. The results are shown in Table 2 . The cell under analysis has been manufactured aiming for a Ni/YSZ volume ratio of 40/60 vol\%, therefore the minimum theoretical pore phase fraction obtainable after $\mathrm{NiO}$ reduction will be $\sim 22 \%$. This in turn leads to an upper limit for $\mathrm{Ni}$ phase fraction of $31.2 \%$. The computed Ni phase fraction of $30 \%$ for the reference cell is in good alignment with manufacturing data. A decrease of overall Ni phase in the active fuel electrode to approximately $23 \%$ in the inlet side of the tested cell was observed. Meanwhile, the porosity showed an increase from $25 \%$ calculated for the reference cell to $29 \%$ after the test, both at the inlet and at the outlet. While the percentage of YSZ at the inlet side is almost un-changed compared to that of the reference cell, an apparent decrease is observed at the outlet side. Such a decrease can be attributed to the uncertainty of the measurement itself, as it will be explained later. The general trend observed in the present study for the Ni phase fraction is in agreement with 
[34]. Performing the quantification of microstructural parameters in the innermost $8 \mu \mathrm{m}$ of the electrode 210 provides important information on the degradation of the active part of the fuel electrode. In the data analysis, 211 the volume between 3 and $11 \mu \mathrm{m}$ from the electrolyte interface was used for deducing microstructural characteristics from the reconstructions. It should be noted that besides the Ni depletion observed in this zone (Table 2) an even stronger depletion is seen close to the electrolyte (Figure 3 a)), within the first three microns, which is not included in values behind Table 2. Estimating accurate confidence intervals for parameters calculated from 3D image data is notoriously challenging. It is worth mentioning that several sources of errors can bias the results: local variations of the structure, representative volume size, a subjective segmentation step, finite resolution, and the parameter estimation method itself [35 - 37]. This is compounded by different parameters having very different sensitivity to each of these types of errors. The equipment used for recording the data combined with the implemented post-processing procedure allowed analysis of volumes of $12.5 \mathrm{x} 8 \mathrm{x}$ $20 \mu \mathrm{m}^{3}$ for each sample. Considering the mean radius of Ni particles $\sim 1.26 \mu \mathrm{m}$ [29] for the cell analyzed in the current work and using the definition of dimensionless length given by Harris et al. [36], the dimensionless uncertainty intervals estimations reported in Table 2. The tortuosity factor is one of the parameters most affected by the size of the volume analyzed in particular when the percolation factor is low; in line with this, was sintered at $1300{ }^{\circ} \mathrm{C}$ and is unaffected by cell operation at $750{ }^{\circ} \mathrm{C}$. For example, there is a discrepancy in 
234 inlet and $43 \% \pm 2.50$ at the outlet. This measurement provides an estimate for the uncertainty level for the 235 calculated phase fractions.

\section{Interface areas and TPB length:}

237 The surface area of each phase and the interface area between phases are used for the evaluation of microstructural changes occurring in the Ni/YSZ electrode due to the long-term operation of the cell. The 239 results are summarized in Table 2 . The overall surface area of $\mathrm{Ni}$ is decreased from $\sim 1.7$ to $\sim 0.9 \mu \mathrm{m}^{2} / \mu \mathrm{m}^{3}$ 240 after long-term operation. The interface areas of pore and YSZ with Ni show a reduction after the testing reaching $\sim 0.3$ and $\sim 0.7 \mu \mathrm{m}^{2} / \mu \mathrm{m}^{3}$ at the inlet side, respectively. The results point out similar degradation at inlet and outlet side of the same cell after 1 year of operation, though to different degrees.

It is well known that electrochemical reactions inside the cell occur at active TPB sites only and these sites need to be part of a percolating TPB to be active. A percolated site is obtained when the three phases defining the TPB each have a percolating path for the conducted species (i.e. electrons through $\mathrm{Ni}$, oxygen ions through YSZ and gas through pores). Table 2 shows the results obtained from the computation of the TPB in the samples analyzed. The length of total and percolating TPB was obtained as the average of the length computed in each of the six directions of the 3D geometry analyzed. Table 2 shows that also the percentage of active sites decreases after the long-term test. While $86 \%$ of the overall TPB length was percolating in the reference cell, only $53 \%$ was percolating at the inlet of the tested cell. A significant difference can be appreciated in the loss of active TPB sites between inlet and outlet, where $62 \%$ of the TPB is percolating at the outlet.

While similar nickel depletion in the active electrode can be detected at the inlet and outlet side of the cell, a more pronounced TPB length decrease is observed at the inlet side when compared to the outlet. This effect is presumably linked with an effect of the local polarization, which is much larger at the inlet compared to the outlet (the total cell overpotential was estimated to be $\sim 420 \mathrm{mV}$ at the inlet and $\sim 320 \mathrm{mV}$ at the outlet) resulting also in a higher local current density [38]. The same trend obtained in the cell analyzed in this study was qualitatively observed in the $\sim 700$ hours tested cells in reference [39], where 2D low voltage SEM images showed a lower percolation degree at the inlet side. Moreover, the higher steam content at the gas inlet side of 
the cell could contribute to the higher degradation observed there. Pihlatie et al. [40] observed that the cell conductivity decreases as the steam content increases. Indeed, high steam content in the fuel promotes the formation of $\mathrm{Ni}(\mathrm{OH})_{2}$ complex that facilitates nickel diffusion and particles growth. In addition to that, the steam content and the local polarization of the electrode affect the local $\mathrm{pO}_{2}$ in the electrode that in turn influences the wettability of $\mathrm{Ni}$ on YSZ. Experimental evidence of the effect of oxygen activity on Ni/YSZ interaction was presented by Jiao et al. [41] and a theoretical correlation between $\mathrm{pO}_{2}$ and $\mathrm{Ni}$ contact angle on YSZ was proposed. Different wettability properties of Ni/YSZ cermets were qualitatively observed in [8] and [39] between the inlet and the outlet of the cell where both gas composition and current density assume different values.

Phase fractions as a function of distance from the electrolyte-fuel electrode interface:

Figure 3 illustrates the phase fraction calculated on each slice of the segmented volume parallel to the electrode-electrolyte interface (i.e. the distance between the two neighboring slices is between $35 \mathrm{~nm}$ and 40 $\mathrm{nm})$. The overall length covered by this analysis is $\sim 16 \mu \mathrm{m}$ for each sample. In the graphs of Figure 3 the electrolyte is located to the left. Two vertical-dashed black lines indicate the region used for the computation of the other microstructural parameters reproduced in Table 2 . This region starts $\sim 3 \mu \mathrm{m}$ away from the electrode-electrolyte interface and ends approximately $1 \mu \mathrm{m}$ before the support layer. Due to the irregular structure, it is not easy to define precisely where the interface between the electrode and the electrolyte is placed. Conventionally, we placed the interface where the first nickel particle is found when moving from the electrolyte towards the electrode. As evident from Figure 3 a significant decrease of the Ni content in the active area is observed after long-term operation at both the inlet and the outlet of the cell to more or less similar extent. In the support, on the other hand, no such depletion is observed, the Ni content in each slice of the support layer in the tested cell is not much different from the one in the reference cell. In consistency with the finding on the Ni phase Figure $3 \mathrm{~b}$ ) shows a slight increase in porosity in the active fuel electrode after 1 year of cell operation, whereas the porosity in the support layer after the long-term operation is not significantly different from the reference one. The content of the YSZ along the direction perpendicular to the electrodeelectrolyte interface is illustrated in Figure $3 \mathrm{c}$ ). It is evident as the YSZ fraction in the electrode does not 
change on aging. Even though Ni migration can be qualitatively appreciated in Figure 3, the local 3D analysis performed in this study does not allow the observation of whereto the Ni moves due to the intrinsic limitation of the analyzed volume with FIB-SEM tomography. Among the factors that lead to uncertainty in the analysis, it must be remembered that raw FIB-SEM data were recorded and segmented such that the focus was on the inner active fuel electrode. This means that data away from this region (i.e. the support layer) are more likely to be affected by artifacts occurring in the segmentation process of the whole volume.

291

Figure 4 shows the results of the EDS analysis. Based on 1 to 5 measurements at different places in each of the samples of interest, the $\mathrm{Ni} /(\mathrm{Zr}+\mathrm{Y})$ atomic ratio was computed on a region of the electrode close to the electrolyte interface and on a larger area of the support layer. The results are illustrated in Figure 4 a). The ratio shown in Figure 4 a) is an indication of the Ni content in the different areas of the electrode. The intrinsic uncertainty of the characterization method and the inhomogeneity of the sample can affect the measurement of the nickel content. In this regard, 9 measurements were performed in the active electrode and 4 EDS maps were recorded for the large area analyzed in the support layer. In order to give an estimation of the inaccuracy of the measures, the standard deviation was computed to be $\sim 0.18$ and $\sim 0.07$, respectively for the active electrode and the support layer. A significant nickel depletion in the region of the active electrode closest to the electrolyte is observed at both inlet and outlet of the tested cell. $\mathrm{A} \mathrm{Ni} /(\mathrm{Zr}+\mathrm{Y})$ atom ratio of approximately $\sim 1.7$ was obtained for the reference cell while the value drops below 1 in both locations of the tested cell. This indicates that the migration of nickel away from the interface between the Ni/YSZ electrode and the electrolyte occurs to similar extents at the inlet and the outlet side of the cell. Interestingly, the $\mathrm{Ni} /(\mathrm{Zr}+\mathrm{Y})$ atom ratio computed on the large area of the support layer does not vary considerably in the regions analyzed and it varies between 1.6 and 1.8 for the three samples as shown in Figure 4 a).

Line scans were recorded starting from the electrolyte toward the support layer and used as further evidence of nickel depletion in the active fuel electrode. The results are summarized in Figure 4 b). The graph in Figure $4 \mathrm{~b}$ ) shows three line scans for the three locations of interest (i.e. reference, inlet and outlet) and the theoretical $\mathrm{Ni} /(\mathrm{Ni}+\mathrm{Y}+\mathrm{Zr})$ atomic ratio of $\sim 67 \%$ resulting from the production process (dashed gray line). The black dashed line points out the electrode-electrolyte interface. The line scan results are in agreement with what 
observed in Figure 3 and Figure 4 a). A systematic decrease in Ni content in the $5 \mu \mathrm{m}$ of the active fuel 312 electrode closest to the electrolyte is recorded after long-term operation while only small variations can be appreciated in the support layer.

\section{$\underline{\text { Particle size distributions: }}$}

315 When performing the microstructural characterization of SOC electrodes it is useful to define the particle sizes. In this work, the continuous particle size distribution method [26] was applied to compute the results shown

in Figure 5. For what concerns Ni particles, it was observed that the average particle radius is subjected to a shift from approximately $350 \mathrm{~nm}$ in the reference cell to $\sim 600 \mathrm{~nm}$ in both locations analyzed on the long-term tested cell. A shift towards larger pore sizes was observed at both analyzed locations of the tested cell compared to the reference cell, the measured YSZ particle size distribution is unaffected by the long-term operation. This observation is well in line with previous studies $[8,28,29]$ and the trend observed for Ni particles agrees with the analysis performed by Hauch et al. [34], where the mean intercept length principle was applied on 2D SEM micrographs and an increase in Ni particle size from $\sim 1.01 \mu \mathrm{m}$ in the reference cell to $\sim 1.26 \mu \mathrm{m}$ in the tested one was observed. These results are in line with the particles size distribution obtained from the analysis of 2D SEM images of the same cell analyzed here, the increase of Ni particle size from $\sim 1.03 \pm 0.02 \mu \mathrm{m}$ in the reference cell to $\sim 1.39 \pm 0.03 \mu \mathrm{m}$ at the inlet side of the tested cell was observed [29]. The testing conditions used for the cells analyzed in [34] were different from the ones applied to the stack analyzed leading to different values of the Ni particles radius. However, the trend is the same in both cases.

Characteristic pathway diameter and Ni tortuosity:

The concept of characteristic pathway diameter has been used in other studies [29, 32], however, there using the term "critical pathway radius" instead. The characteristic pathway diameter is the diameter of the largest sphere that can be squeezed through the network of the phase of interest. This idea is sketched in Figure 6 where percolating TPBs are highlighted and possible pathways of electrons in the Ni phase are drawn. The characteristic pathway diameter is pointed out in Figure 6 by red arrows. 
The characteristic pathway diameter is a measure to evaluate the quality of the pathway connections of the different phases; i.e. the width of the "Nickel highway" for the electrons and similar for the gas phase in the pores and oxide ions in the YSZ phase. This parameter is important for understanding the quality of the pathways connecting the three phases throughout the electrode. If the percolation of TPB sites is guaranteed by pathways characterized by a very narrow diameter (e.g. $20 \mathrm{~nm}$ ), then impurities, carbon deposition or similar situated at the TPB may more easily break the network connectivity and therefore reduce the degree of electrode percolation in the overall cell performance. On the other hand, if the pathway is characterized by a larger characteristic diameter (e.g. $200 \mathrm{~nm}$ or above), the structure is more robust and impurities are less likely to obstruct the connectivity. A significant change of the characteristic pathway diameter for the Ni phase can be observed in Figure 7 a). Assuming for instance that a high performing cell is characterized by Ni connected through pathways with a diameter around $200 \mathrm{~nm}$, the percentage of paths with this characteristic is higher than $80 \%$ in the reference cell and is below $50 \%$ at both the inlet and the outlet side of the tested cell. After testing, the pores are connected through bigger paths as illustrated in Figure 7 b) whereas YSZ does not show appreciable changes with respect to characteristic pathway diameter (Figure $7 \mathrm{c}$ )).

349 The results illustrated in Figure 7 confirm the degradation trend observed in Figure 5: the characteristic 350 diameters of percolated pathways are degraded significantly to a similar degree for both the inlet and outlet part of the cell after one year of testing.

The results in Table 2 show lower values of percolating TPB at the inlet side while the graphs presented in 353 Figure 7 report lower nickel percolation at the outlet. This effect could be due to the fact that the percolating 354 TPB length is computed by checking the percolation through all the three phases. Instead, the characteristic pathway diameter shown in Figure 7 consider the individual percolation of each phase separately. One more parameter that can be used as indication of networking quality is the tortuosity factor. This parameter was computed using the TauFactor program [33]. The results are reported in Table 2, for Ni and pore phases of the active fuel electrode. Increased tortuosity of the Ni networking and therefore pronounced degradation can be appreciated when comparing the tested cell with the reference, although a clear difference between inlet and 
outlet cannot be detected. The tortuosity factor computed on the pore phase reveals reduced tortuosity in the tested cell compared to the reference.

\section{Discussion}

The locations investigated in this study were exposed to different local conditions: gas compositions, current densities and temperatures inside the tested cell. The results presented here on phase fraction (Table 2) and Ni migration (Figure 3) are in agreement with Mogensen et al. [39] where a study of Ni migration correlated with current load is reported for SOFC and SOEC. In electrolysis mode, a loss of Ni in the innermost active fuel electrode was observed [39]. A qualitative comparison between inlet and outlet based on 2D SEM images after $\sim 700$ hours of testing is reported in reference [39] showing appreciable bigger Ni particle size and higher percolation loss at the inlet than at the outlet side. The results for Pore/Ni and YSZ/Ni interface area summarized in Table 2 show a decrease of approximately $69 \%$ and $29 \%$, respectively, when comparing the inlet side of the tested cell with the reference cell. The difference in the extend of the decrease can be related to the inhibiting effect of YSZ on Ni coarsening as discussed in [40, 42]. Huber et al. [42] observed that the morphological variation of nickel during the coarsening process is more pronounced on the Ni surface in contact with the gas phase than at the YSZ/Ni interface. Indeed, the energy related to the Pore/Ni interface is lower than the energy related to the adhesion of Ni on YSZ. This results in the smaller decrease of YSZ/Ni interface area when compared to the decrease of Pore/Ni interface area (Table 2). The Ni rearrangements observed in the cell investigated in this work are well in line with the observations of Hubert et al. [42] where the inhibiting effect of the YSZ skeleton on Ni coarsening at typical SOC operating temperature was pointed out. The homogenization of microstructural parameters as observed here after one year of electrolysis operation leads to the tentative conclusion that the different conditions experienced by the cell at the two extremities are more important in the first hundreds of hours of cell life. On the other hand, different percolation degrees through the Ni phase were observed at the two extremities of the cell after the long-term testing showing, when using this parameter, the most severe change to the Ni network at the inlet where the cell is more polarized. 
All the microstructural features investigated in this study pointed out significant degradation both at the inlet and the outlet of the tested cell that was used in a 25-cell stack compared to the non-tested reference cell. Moreover, the degree of degradation of the two locations analyzed in the tested cell shows similar trends and only some microstructural parameters (e.g. TPB length) indicate significant difference between the inlet and the outlet side of the tested cell. Several studies proved that the Ni particle size increases mainly in the first thousands of hours of testing [28, 43-45] and only small modification can be detected afterwards. After 1 year of operation, as it is the case in the current study, the coarsening rate of $\mathrm{Ni}$ in the electrode is supposed to be slow. This would explain the almost identical Ni PSD at the inlet and the outlet side of the long-term tested cell shown in Figure 5. Moreover, the local testing conditions between inlet and outlet will make the degradation occurring first at the inlet side and with the time also at the outlet. Ni rearrangement dictates changes in porosity and therefore a significant difference in pore size between the reference and the tested cell can be detected, however the size of the pores computed on the tested cell is almost unchanged between the two locations analyzed. A number of tests under the same operating conditions (temperature, current density, polarization, and gas composition) but for different time duration have been run in order to investigate intermediate stage of degradation. The Ni/YSZ electrode microstructure is currently being characterized and the results will be reported elsewhere.

The results for the characteristic pathway diameter illustrated in Figure 7 highlight a significant reduction in percolation through the nickel phase, the total amount of pathways percolated throughout the volume (i.e. percolating TPB sites) decreases strongly. Nevertheless, the diameters of the pathways that remain percolated shows a mild increase. This could be the effect of a microstructural degradation driven by curvature minimization. The effect of this process will lead to the disconnection of pathways connected through small 405 bottlenecks while a more stable behavior during operation will be observed for wider pathways characterized by low curvature resulting in an overall decrease in percolation but an increase of the characteristic pathway diameter for the remaining Ni pathways. De Angelis et al. [46] used x-ray tomography for investigating $\mathrm{Ni} / \mathrm{YSZ}$ cermets evolution. They observed that nickel coarsening leads to a loss of nickel connectivity and an 
improvement in connectivity through the pore phase. The reduced tortuosity for the pore phase reported in Table 2 finds an explanation in the improved connectivity of the pores.

An additional effect of the coarsening process is the increase of particle size shown in Figure 5: smaller nickel particles are present in the reference cell after the reduction of $\mathrm{NiO}$ to $\mathrm{Ni}$, these particles are characterized by high curvature and disappear during the coarsening process in favor of bigger features with lower curvature.

TPB sites were quantified after segmentation for each of the three volumes analyzed and given in Table 2. The lower percentage of percolated sites computed at the inlet side of the tested cell compared to the outlet is in agreement with the observation reported by Mogensen et al. [39] and by Hauch et al. [8 (Cell A and B)] at the cell level, Fang et al. [14] reported similar funding at the stack level . The inlet side is supposed to be exposed to highest value of local current density which can contribute to a faster degradation. Chen et al. [38] simulated the current density distribution in the cell in the direction of the steam flow for two cells with different oxygen electrodes, the average current density of the two cells was $\sim 0.9$ and $\sim 1.2 \mathrm{~A} / \mathrm{cm}^{2}$, respectively [38]. The differences between inlet and outlet in current density were $\sim 0.19$ and $\sim 0.35 \mathrm{~A} / \mathrm{cm}^{2}$, for the two cells respectively. A rough estimation of the difference in current density between inlet and outlet for the cell analyzed in the current study can be done considering that such a difference is approximately $20 \%$ of the average value. Therefore, for the current case we can estimate the difference to be $\sim 0.14 \mathrm{~A} / \mathrm{cm}^{2}$ resulting in $0.79 \mathrm{~A} / \mathrm{cm}^{2}$ at the inlet side and $\sim 0.65 \mathrm{~A} / \mathrm{cm}^{2}$ at the outlet. Starting from $86 \%$ of active TPB sites for the reference cell only $62 \%$ and $53 \%$ were found at the outlet and the inlet of the tested cell, respectively. Knibbe et al. [7] and Chen et al. [11] investigated the effect of the current density on the Ni/YSZ electrodes microstructure. Ni coarsening and re-distribution were the main effects when the cells were tested at a current density below $-1 \mathrm{~A} / \mathrm{cm}^{2}$ (the cells were tested at 800 and $850{ }^{\circ} \mathrm{C}$ and an estimated fuel electrode polarization of $\sim 50-150 \mathrm{mV}$ ) [11]. For higher values of current density the formation of nanoparticles and impurities, and the detachment of Ni from the YSZ scaffold were observed in the microstructures $[7,11]$. These phenomena contributed to the more pronounced performance degradation observed at higher current density $[7,11]$. The low current density used for the stack examined in the present study can explain the lack of nanoparticles at the interfaces between $\mathrm{Ni}$ and YSZ as observed in [7] and [11] for higher value of current density and local 
polarization. These percolating TPB results also fit well with the analysis of characteristic pathway diameter and the tortuosity factor, which reveal that the one-year test has weakened transport properties of the Ninetwork: there is a loss in TPB percolation through the Ni phase and an increase in the tortuosity factor of the Ni network for the conduction of electrons.

Not many studies focused on the quantification of SOEC microstructure parameters. Jørgensen and Bowen [25] determined microstructural parameters for a single SOEC tested for approximately 1300 hours [25, 34] where the same method for the calculation of TPB was implemented. In that specific case, $80 \%$ of the TPB was percolating after the testing. The higher percolation recorded in [25] could be due to several factors such as shorter testing time, lower current density $\left(-0.5 \mathrm{~A} / \mathrm{cm}^{2}\right)$ and therefore lower fuel electrode overpotential, and also to the different gas composition used $\left(50 \%\right.$ steam and $\left.50 \% \mathrm{H}_{2}\right)$ versus the here used 90/10. More details on the testing parameters can be found in [34]. A quantification of SOEC Ni/YSZ electrode microstructure was performed also in [47] where the total TPB length was computed to be $4.63 \mu \mathrm{m} / \mu \mathrm{m}^{3}$ with $3.07 \mu \mathrm{m} / \mu \mathrm{m}^{3}$ of active sites in the commercial cell analyzed [48] versus the here reported $3.28 \mu \mathrm{m} / \mu \mathrm{m}^{3}$ and $2.83 \mu \mathrm{m} / \mu \mathrm{m}^{3}$.

Here, the reference cell could be compared only with one more step in time the full 9000 hours. However, a previous study [39] has showed a difference in the rate of degradation of the percolation between the inlet and the outlet side of the cell. After 128 hours the degradation is more marked at the inlet than at the outlet while after 678 hours of test the difference started disappearing [39]. Similar results showing a faster degradation at the inlet than at the outlet were also reported by Hauch et al. [8 (Cell A and B)]. Further, analyses of the

The results presented in this work show that differences between the inlet and the outlet of the cell after longterm testing could be detected only for some of microstructural parameters. TPB length illustrates recognizable differences between the inlet and the outlet of the tested cell. The trend already reported in other studies [8 (Cell A and B), 14, 39] (i.e. lower degradation rate at the outlet side) was also observed here but only through some of the features considered. Based on the results of the current and previous studies [29], we hypothesize herein that the degradation of the investigated cell is connected to different local operating conditions 
experienced at the two extremities. In particular, current distribution and gas composition are thought to play an important role for the differences in degradation.

The characterization performed in this paper provides suitable input for microstructural modelling. The 3D reconstruction of the reference cell could be used as input for the modelling and microstructural parameters can be computed on the simulated geometries and linked to the experimental results presented in this work. The investigation of the modelling results can provide information on the intermediate stages of the coarsening process and related microstructural changes that cannot be detected and quantified during the operation of the cell.

\section{Conclusion}

A detailed 3D microstructural characterization of a solid oxide electrolysis cell that was operated as part of a stack for one year was performed, and microstructural parameters were compared with the results obtained on a non operated reference cell manufactured as a part of the same batch of cells.

The depletion of Ni in the region close to the electrode-electrolyte interface $(\sim 5 \mu \mathrm{m})$ emerged both from the EDS results and from the analysis of the three dimensional reconstructions. This effect was observed to occur both at the inlet and at the outlet side of the cell after the long-term test in electrolysis mode. The same type of analysis performed on the YSZ shows the stability of this phase during the cell aging.

The long-term test strongly affected the microstructure, starting from a reference cell with $86 \%$ of percolating sites, to $62 \%$ at the outlet side and only $53 \%$ at the inlet side after the test. Moreover, the shift towards larger particles size together with the decrease of TPBs percolation and the increase of the tortuosity factor of the nickel show a strong degradation in the network-quality of the three interpenetrating phases in the cermet. This fact is likely responsible for the majority of the resistance increase observed over the one year aging: a resistance increase (ASR) of 42\% was observed over 9000 hours test. [31]. 
484 Interestingly, the two locations investigated on the tested cell (i.e. inlet and outlet side) showed similar 485 characteristics in microstructural changes/degradation, slightly more pronounced at the inlet. The higher loss 486 of percolating TPB at the inlet side is likely due to the more harsh operating conditions experienced here: 487 larger current density (stronger polarization) and more moist gas composition.

\section{Acknowledgement}

491 This work was financially supported by the projects "Synfuel" (4106-00006B) from Innovation Fund 492 Denmark and EUDP project no. 64017-0011 "EP2Gas - Efficient Power2Gas combining SOEC and 493 biomass gasification”. Moreover, the authors would like to thank postdoc Salvatore De Angelis and 494 staff at Haldor Topsøe A/S for their technical support.

495 


\section{Bibliography}

1. P. Taylor, A. Smith, A. S. Pedersen, "Fuel Cells", Encyclopedia of Environmental Management Fuel Cells, 37-41 (2014), doi:10.1081/E-EEM-120050576

2. P. Taylor, A. Smith, A. S. Pedersen, "Electrolysis", Encyclopedia of Environmental Management Fuel Cells, 37-41 (2014), doi:10.1081/E-EEM-120050577

3. L. Becero, "Recent advances in high temperature electrolysis using solid oxide fuel cells : A review", $J$. Power Sources 203, 4-16 (2012).

4. S. D. Ebbesen, J. S. Højgaard, A. Hauch, and M. B. Mogensen, "High Temperature Electrolysis in Alkaline Cells, Solid Proton Conducting Cells, and Solid Oxide Cells", Chem. Rev. 114, 10697-10734 (2014).

5. D. S. Ebbesen, C. Graves, A. Hauch, S. H. Jensen, and M. B. Mogensen, "Poisoning of Solid Oxide Electrolysis Cells by Impurities”, J. Electrochem. Soc. 157(10) B1419-B1429, (2010), doi:10.1149/1.3464804

6. Q. Fu, C. Mabilat, M. Zahid, A. Brisse, and L. Gautier, "Syngas production Via high-temperature steam/CO2 co-electrolysis: an economic assessment", H. O. T. Energy \& Environmental Science (2010), doi:10.1039/c0ee00092b

7. R. Knibbe, L. Traulsen, A. Hauch, S. D. Ebbesen, and M. B. Mogensen, "Solid Oxide Electrolysis Cells : Degradation at High Current Densities", J. Electrochem. Soc. 157(8) B1209-B1217 (2010), doi:10.1149/1.3447752

8. A. Hauch, K. Brodersen, M. Chen, and M. B. Mogensen, "Ni / YSZ electrodes structures optimized for increased electrolysis performance and durability", Solid State Ionics 293, 27-36 (2016).

9. J. Schefold, A. Brisse, and F. Tietz, "Nine Thousand Hours of Operation of a Solid Oxide Cell in Steam Electrolysis Mode", J. Electrochem. Soc. 159(2), A137-A144 (2012)

10. F. Tietz, D. Sebold, A. Brisse, and J. Schefold, "Degradation phenomena in a solid oxide electrolysis cell after 9000 h of operation", J. Power Sources 223, 129-135 (2013).

11. M. Chen, Y. L. Liu, J. J. Bentzen, W. Zhang, X. Sun, A. Hauch, Y. Tao, J. R. Bowen, and P. V. Hendriksen, "Microstructural Degradation of Ni / YSZ Electrodes in Solid Oxide Electrolysis Cells under High Current", J. Electrochem. Soc. 160(8) F883-F891 (2013).

12. L. Holzer, B. Iwanschitz, T. Hocker, B. Münch, M. Prestat, D. Wiedenmann, U. Vogt, P. Holtappels, J. Sfeir, A. Mai, and T. Graule, "Microstructure degradation of cermet anodes for solid oxide fuel cells: Quantification of nickel grain growth in dry and in humid atmospheres", J. Power Sources 196, 1279-1294 (2011).

13. A. Faes, D. Presvytes, C. G. Vayenas, and J. Van "Nickel - Zirconia Anode Degradation and Triple Phase Boundary Quantification from Microstructural Analysis", Fuel Cells 9(6), 841-851 (2009), doi:10.1002/fuce. 200800147 
14. Q. Fang, C. E. Frey, N. H. Menzler, and L. Blum. "Electrochemical Performance and Preliminary PostMortem Analysis of a Solid Oxide Cell Stack with 20,000 h of Operation", J. Electrochem. Soc. 165(2) F38F45 (2018).

15. C. Graves, Reversing and Repairing Microstructure Degradation in Solid Oxide Cells During Operation. ECS Tran., 57(1) 3127-3136 (2013), 10.1149/05701.3127ecst

16. H. Yokokawa, H.Tu, B, Iwanschitz, and A. Maic, "Fundamental mechanisms limiting solid oxide fuel cell durability", J. Power Sources 182, 400-412 (2008).

17. D. Waldbillig, A. Woodb, and D.G. Ivey, "Electrochemical and microstructural characterization of the redox tolerance of solid oxide fuel cell anodes", J. Power Sources 145, 206-215 (2005).

18. Y.L. Liu, and C, Jiao, "Microstructure degradation of an anode/electrolyte interface in SOFC studied by transmission electron microscopy", Solid State Ionics 176, 435-442 (2005).

19. P. R. Shearing, J. Golbert, R. J. Chater, and N. P. Brandon, "3D reconstruction of SOFC anodes using a focused ion beam lift-out technique”, Chem. Eng. Sci. 64, 3928-3933 (2009).

20. H. Iwai, N. Shikazono, T. Matsui, H. Teshima, and M. Kishimoto, "Quantification of SOFC anode microstructure based on dual beam FIB-SEM technique”, J. Power Sources 195, 955-961 (2010).

21. J. R. Wilson, M. Gameiro, K. Mischaikow, W. Kalies, P. W. Voorhees, and S. A. Barnett, "ThreeDimensional Analysis of Solid Oxide Fuel Cell Ni-YSZ Anode Interconnectivity". Microsc. Microanal. 15, 71-77 (2017).

22. P. S. Jørgensen, S. L. Ebbehøj, and A. Hauch, "Triple phase boundary specific pathway analysis for quantitative characterization of solid oxide cell electrode microstructure Publication date: Triple phase boundary specific pathway analysis for quantitative characterization of solid oxide cell electrode", J. Power Sources 279, 686-693 (2015).

23. T. Shimura, Z. Jiao, S. Hara, and N. Shikazono, "Quantitative analysis of solid oxide fuel cell anode microstructure change during redox cycles”, J. Power Sources 267, 58-68 (2014).

24. P. S. Jørgensen, K. V. Hansen, R. Larsen, and J. R. Bowen, “Geometrical characterization of interconnected phase networks", Journal Microsc. 244, 45-58 (2011).

25. P. S. Jørgensen, and J. R. Bowen, "Determination of Three Dimensional Microstructure Parameters from a Solid Oxide Ni/YSZ Electrode after Electrolysis Operation”, ECS Tran. 35(1), 1655-1660 (2011), $10.1149 / 1.3570152$

26. B. Münch, and L. Holzer, "Contradicting Geometrical Concepts in Pore Size Analysis Attained with Electron Microscopy and Mercury Intrusion”, J. Am. Ceram. Soc. 91 (12) 4059-4067, (2008).

27. P. Hjalmarsson, X. Sun, Y.-L. Liu, and M. Chen, "Durability of high performance Nieyttria stabilized zirconia supported solid oxide electrolysis cells at high current density", J. Power Sources 262, 316-322 (2014). 
28. P. Tanasini, M. Cannarozzo, P. Costamagna, A. Faes, J. Van Herle, A. Hessler-Wyser, and C. Comninellis, "Experimental and Theoretical Investigation of Degradation Mechanisms by Particle Coarsening in SOFC Electrodes", Fuel Cells 9(5), 740-752 (2009), doi:10.1002/fuce.200800192

29. M. Trini, P. S. Jørgensen, A. Hauch, M. Chen, P. V. Hendriksen, "Microstructural Characterization of Ni/YSZ Electrodes in a Solid Oxide Electrolysis Stack Tested for 9000 Hours", ECS Tran. 78 (1), $3049-3064$ (2017), 10.1149/07801.3049ecst

30. G. Rinaldi, S. Diethelm, E.Oveisi, P. Burdet, J. V. Herle, D. Montinaro, Q. Fu, and A. Brisse, "Post-test Analysis on a Solid Oxide Cell Stack Operated for 10,700 Hours in Steam Electrolysis Mode", Fuel Cells 17(4), 541-549 (2017).

31. A. Brisse, J. Schefold, G. Corre, and Q. Fu, "Performance and Lifetime of Solid Oxide Electrolyzer Cells and Stacks", 11th European SOFC \& SOE Forum, B1405 48-59 (2014).

32. P. S. Jørgensen, S. L. Ebbehøj, and A. Hauch, "Triple phase boundary specific pathway analysis for quantitative characterization of solid oxide cell electrode microstructure", J. Power Sources 279, 686-693 (2015), doi: 10.1016/j.jpowsour.2015.01.054

33. S. J. Cooper, A. Bertei, P. R. Shearing, J. A. Kilner, and N. P. Brandon, "ScienceDirect TauFactor : An open-source application for calculating tortuosity factors from tomographic data". SoftwareX 5, 203-210 (2016).

34. A. Hauch, S. D. Ebbesen, S. H. Jensen, and M. B. Mogensen, "Solid Oxide Electrolysis Cells: Microstructure and Degradation of the Ni/Yttria-Stabilized Zirconia Electrode", J. Electrochem. Soc., 155(11), B1184-B1193 (2008).

35. P. S. Jørgensen, K. Yakal-kremski, J. Wilson, J. R. Bowen, and S. Barnett, “On the accuracy of triple phase boundary lengths calculated from tomographic image data”, J. Power Sources 261, 198-205 (2014).

36. W. M. Harris, and W. K.S. Chiu, "Determining the representative volume element size for three-dimensional microstructural material characterization. Part 1: Predictive models”, J. Power Sources 282, 552-561 (2015).

37. J. J. Lombardo, R.A. Ristau, W. M. Harris, and W. K. S. Chiu, "Focused ion beam preparation of samples for X-ray nanotomography", J. Synchrotron Radiat 19, 789-796 (2012).

38. M. Chen, X. Sun, C. Chatzichristodoulou, S. Koch, P. V. Hendriksen, and M. B. Mogensen, "Thermoneutral Operation of Solid Oxide Electrolysis Cells in Potentiostatic Mode", ECS Trans. 78(1) 30773088 (2017).

39. M. B. Mogensen, A. Hauch, X. Sun, M. Chen, Y. Tao, S. D. Ebbesen, K. V. Hansen, and P. V. Hendriksen, "Relation Between Ni Particle Shape Change and Ni Migration in Ni-YSZ Electrodes - a Hypothesis", Fuel Cells 17(4), 434-441 (2017).

40. M.H. Pihlatie, A. Kaiser, M. Mogensen, and M. Chen, "Electrical conductivity of Ni-YSZ composites: Degradation due to Ni particle growth”, Solid State Ionics 189, 82-90 (2011).

41. Z. Jiao, and N. Shikazono, "Study on the effects of polarization on local morphological change of nickel at active three-phase-boundary using patterned nickel-film electrode in solid oxide fuel cell anode”, Acta. Mater. 135, 124-131 (2017). 
42. M. Hubert, J. Laurencin, P. Cloetens, B. Morel, D. Montinaro, and F. Lefebvre-Joud, "Impact of Nickel agglomeration on Solid Oxide Cell operated in fuel cell and electrolysis modes”, J. Power Sources 397, 240-251 (2018).

43. R. Vaßen, D. Simwonis, and D. Stover, "Modelling of the agglomeration of Ni-particles in anodes of solid oxide fuel cells", J. Mater. Sci. 36, 147-151 (2001).

44. D. Simwonis, F. Tietz, D. Stover, "Nickel coarsening in annealed Ni / 8YSZ anode substrates for solid oxide fuel cells", Solid State Ionics 132, 241-251 (2000).

45. S. Gao, J. Li, and Z. Lin, "Theoretical model for surface diffusion driven Ni-particle agglomeration in anode of solid oxide fuel cell”. J. Power Sources 255, 144-150 (2014).

46. S. De Angelis, P. S. Jørgensen, E. H. R. Tsai, M. Holler, K. Kreka, and J. R. Bowen, "Three dimensional characterization of nickel coarsening in solid oxide cells via ex-situ ptychographic nano-tomography", $J$. Power Sources 383, 72-79 (2018).

47. F. Usseglio-Viretta, J. Laurencin, G. Delette, J. Villanova, P. Cloetens, and D. Leguillon, "Quantitative microstructure characterization of a Ni e YSZ bi-layer coupled with simulated electrode polarisation", J. Power Sources 256, 394-403 (2014).

48. R. N. Basu, G. Blass, H. P. Buchkremer, D. Stöver, F. Tietz, E. Wessel, and I. C. Vinke, "Simplified processing of anode-supported thin film planar solid oxide fuel cells", J. Eur. Ceram. Soc. 25, 463-471 (2005) 
Table 1: Parameters used for the 1-year stack test [31].

\begin{tabular}{|c|c|c|c|c|c|c|c|c|}
\hline \multirow[t]{2}{*}{$\begin{array}{l}\text { Period } \\
\text { [hours] }\end{array}$} & \multirow[t]{2}{*}{$\begin{array}{c}\text { Temperature } \\
{\left[{ }^{\circ} \mathrm{C}\right]}\end{array}$} & \multirow{2}{*}{$\begin{array}{c}\text { Steam } \\
\text { conversion } \\
{[\%]} \\
\text { (constant) }\end{array}$} & \multirow[t]{2}{*}{$\begin{array}{l}\text { Air flow } \\
\text { [Nl/min] }\end{array}$} & \multicolumn{2}{|c|}{$\begin{array}{c}\text { Steam[\%]/ } \\
\text { Hydrogen [\%] } \\
\text { feed }\end{array}$} & \multirow[t]{2}{*}{$\begin{array}{l}\text { Hydrogen } \\
\text { flow } \\
{[\mathrm{Nl} / \mathrm{min}]}\end{array}$} & \multirow{2}{*}{$\begin{array}{l}\text { Current } \\
\text { density } \\
{\left[\mathrm{A} / \mathrm{cm}^{2}\right]}\end{array}$} & \multirow[t]{2}{*}{$\begin{array}{c}\text { Degradation } \\
{[\% / 1000 \mathrm{~h}]}\end{array}$} \\
\hline & & & & Inlet & Outlet & & & \\
\hline $0-2175$ & \multirow[b]{2}{*}{750} & \multirow[b]{2}{*}{50} & \multirow[b]{2}{*}{28} & \multirow[b]{2}{*}{$90 / 10$} & \multirow[b]{2}{*}{$\begin{array}{c}45 / 55 \\
\text { (calculated) }\end{array}$} & 1.95 & -0.57 & 2.0 \\
\hline $\begin{array}{l}2175- \\
8700\end{array}$ & & & & & & 2.45 & -0.72 & $2.0^{*}$ \\
\hline
\end{tabular}

629

* average value

630

631

632

633

634

635

636

637

638

639

640

641

642

643

644

645 
646 Table 2: Phase fraction, total and percolating TPB and surface area calculated on 3D reconstructions of all the samples 647 for the three phases of interest. Based on cell manufacturing data, the volume ratio between Ni and YSZ can be expected 648 to be Ni/YSZ: 40/60 vol\%.

\begin{tabular}{|c|c|c|c|}
\hline & Reference & Inlet & Outlet \\
\hline $\mathrm{Ni}[\mathrm{vol} \%]$ & $30.16 \pm 2.50$ & $23.80 \pm 2.50$ & $28.37 \pm 2.50$ \\
\hline Pore [vol\%] & $24.66 \pm 2.50$ & $29.06 \pm 2.50$ & $28.95 \pm 2.50$ \\
\hline YSZ [vol\%] & $45.18 \pm 2.50$ & $47.15 \pm 2.50$ & $42.68 \pm 2.50$ \\
\hline Total TPB $\left[\mu \mathrm{m} / \mu \mathrm{m}^{3}\right]$ & $3.28 \pm 0.10$ & $1.44 \pm 0.10$ & $1.67 \pm 0.10$ \\
\hline Percolating TPB $\left[\mu \mathrm{m} / \mu \mathrm{m}^{3}\right]$ & $2.83 \pm 0.15$ & $0.76 \pm 0.15$ & $1.04 \pm 0.15$ \\
\hline Percentage of Percolating TPB [\%] & $86.28 \pm 3.41$ & $52.84 \pm 5.02$ & $62.22 \pm 4.53$ \\
\hline Percentage of Percolating TPB Pore [\%] & $95.11 \pm 10.00$ & $93.22 \pm 10.00$ & $96.29 \pm 10.00$ \\
\hline Percentage of Percolating TPB YSZ[\%] & $98.89 \pm 10.00$ & $98.47 \pm 10.00$ & $98.86 \pm 10.00$ \\
\hline Percentage of Percolating TPB Ni[\%] & $91.60 \pm 10.00$ & $46.52 \pm 10.00$ & $42.96 \pm 10.00$ \\
\hline Pore surface area $\left[\mu^{2} / \mu m^{3}\right]$ & $2.09 \pm 0.05$ & $1.72 \pm 0.05$ & $1.58 \pm 0.05$ \\
\hline YSZ surface area $\left[\mu^{2} / \mu m^{3}\right]$ & $2.09 \pm 0.03$ & $2.07 \pm 0.03$ & $1.92 \pm 0.03$ \\
\hline Ni surface area $\left[\mu \mathrm{m}^{2} / \mu \mathrm{m}^{3}\right]$ & $1.74 \pm 0.05$ & $0.88 \pm 0.05$ & $1.05 \pm 0.05$ \\
\hline Pore/YSZ interface area $\left[\mu \mathrm{m}^{2} / \mu \mathrm{m}^{3}\right]$ & $1.22 \pm 0.05$ & $1.45 \pm 0.05$ & $1.23 \pm 0.05$ \\
\hline Pore/Ni interface area $\left[\mu \mathrm{m}^{2} / \mu \mathrm{m}^{3}\right]$ & $0.87 \pm 0.05$ & $0.27 \pm 0.05$ & $0.35 \pm 0.05$ \\
\hline YSZ/Ni interface area $\left[\mu \mathrm{m}^{2} / \mu \mathrm{m}^{3}\right]$ & $0.87 \pm 0.05$ & $0.62 \pm 0.05$ & $0.69 \pm 0.05$ \\
\hline Ni tortuosity factor direction 1 & $6.27 \pm 2.00$ & $50.50 \pm 20.00$ & $17.80 \pm 20.00$ \\
\hline Ni tortuosity factor direction 2 & $6.64 \pm 2.00$ & $13.70 \pm 5.00$ & $14.60 \pm 5.00$ \\
\hline Ni tortuosity factor direction 3 & $4.49 \pm 2.00$ & $26.40 \pm 15.00$ & $32.00 \pm 15.00$ \\
\hline Pore tortuosity factor direction 1 & $7.25 \pm 2.00$ & $3.69 \pm 2.00$ & $3.34 \pm 2.00$ \\
\hline
\end{tabular}


Pore tortuosity factor direction 2

Pore tortuosity factor direction 3
$5.78 \pm 2.00$

$4.65 \pm 2.00$

$5.01 \pm 2.00$

$5.37 \pm 2.00$

$4.34 \pm 2.00$

$4.00 \pm 2.00$

649

650

651

652

653

654

655

656

657 


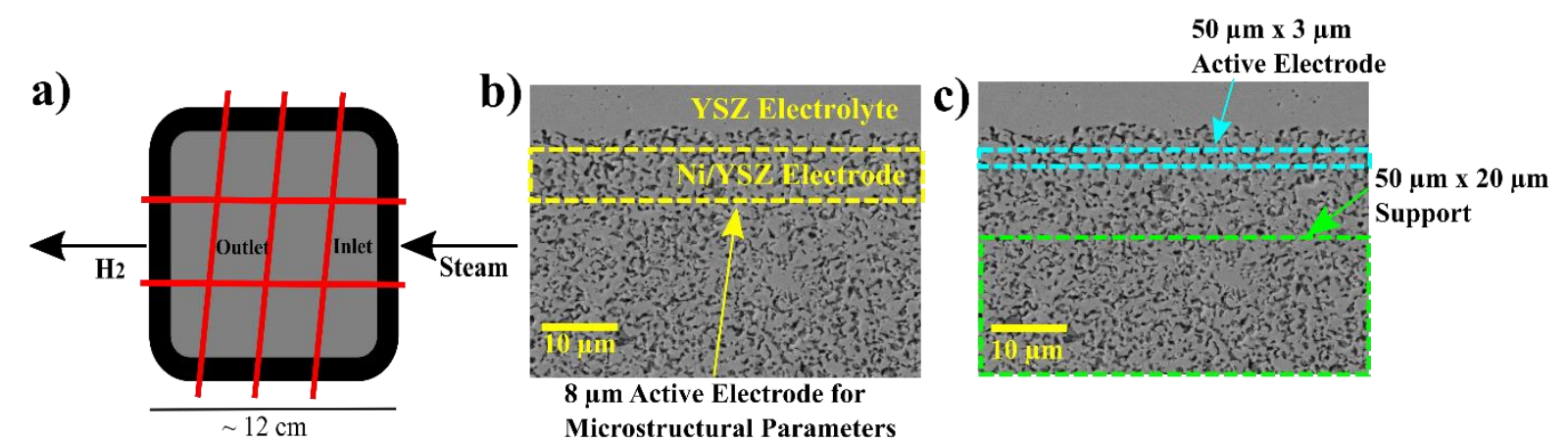

d)

\section{FIB Milling Front}

Direction

659 Figure 1: a) Schematic of stack top view showing the applied sectioning, the steam inlet and outlet are indicated in the electrode of the reference cell highlighting innermost $8 \mu \mathrm{m}$ of the active electrode analyzed in the microstructural characterization. c) Illustration of the regions for the EDS analysis in the support layer and close to the electrodeelectrolyte interface. d) Schematic drawing of electrolyte $(\sim 5 \mu \mathrm{m})$, active fuel electrode $(\sim 15 \mu \mathrm{m})$, and part of the 664 support layer (overall thickness $\sim 300 \mu \mathrm{m}$ ) illustrating the FIB milling front and line scan directions and the width of the 


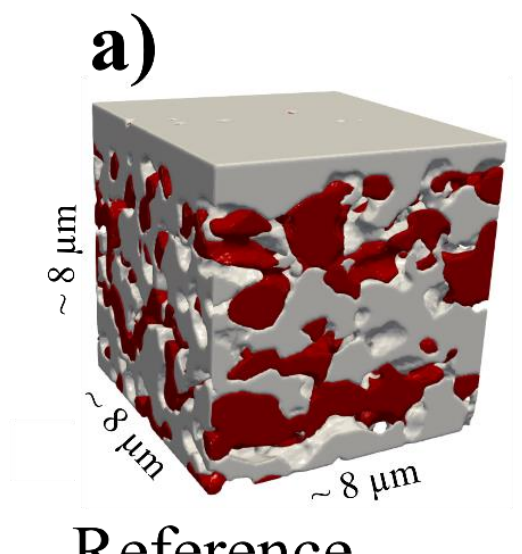

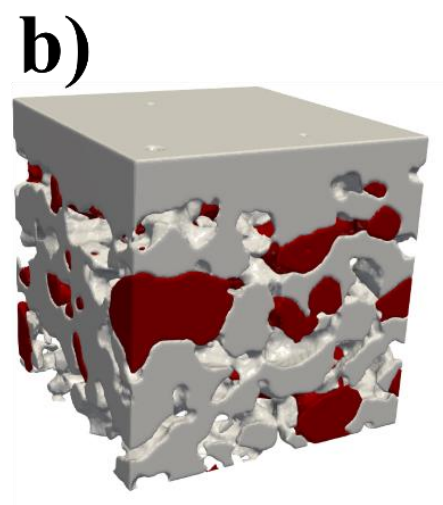

Inlet c)

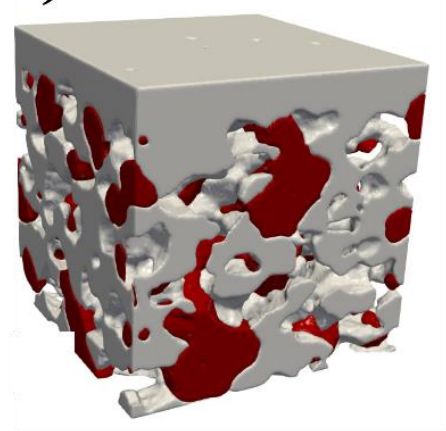

Outlet

673 Figure 2: 3D reconstructions of sub-volumes extracted from: a) reference cell, b) inlet side of the tested cell c) outlet 
a)

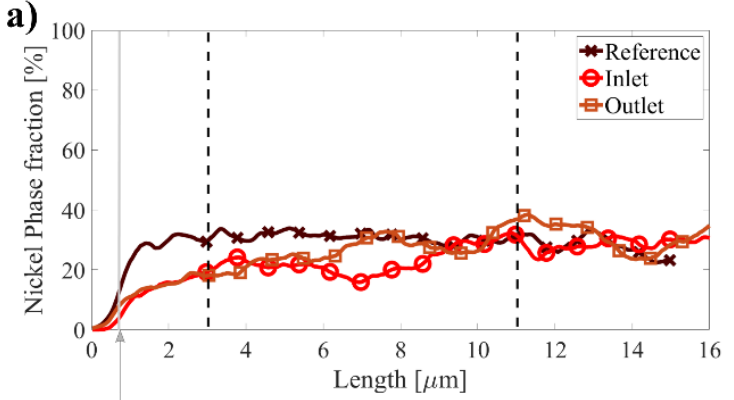

b)

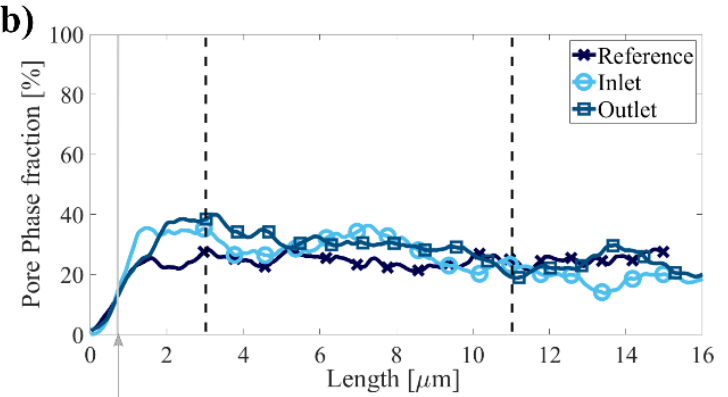

Electrolyte/Electrode interface

Electrolyte/Electrode interface

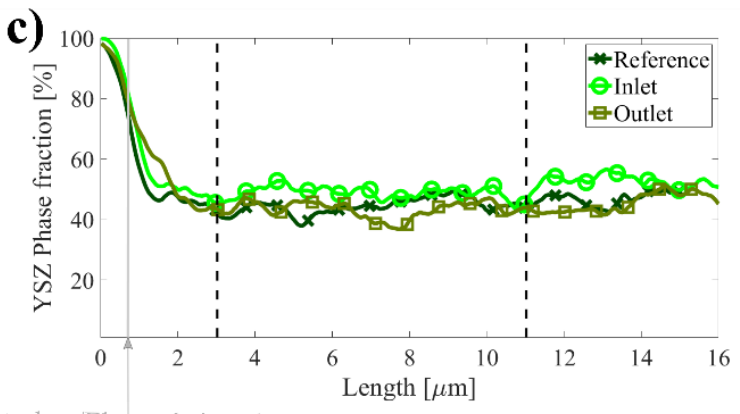

Electrolyte/Electrode interface

683

684 Figure 3: Phase fraction of the three phases form the FIB-SEM reconstructions in the direction perpendicular to the

685 electrode-electrolyte interface: a) Ni, b) pores and c) YSZ. Each graph shows results for the reference cell and the tested

cell at the inlet and the outlet.

687

688

689

690

691

692

693

694

695 
a)

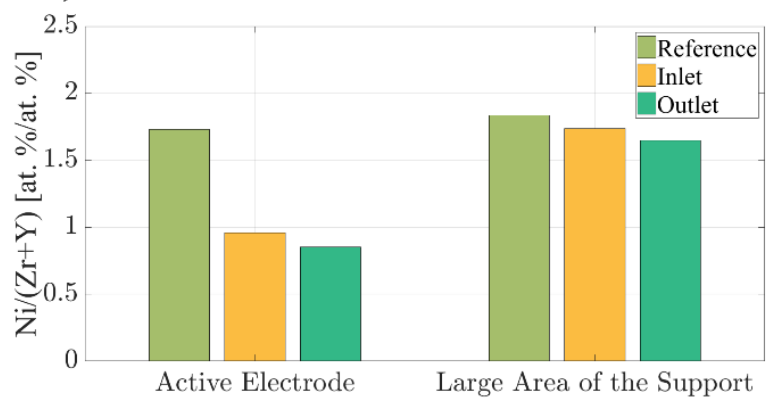

b)

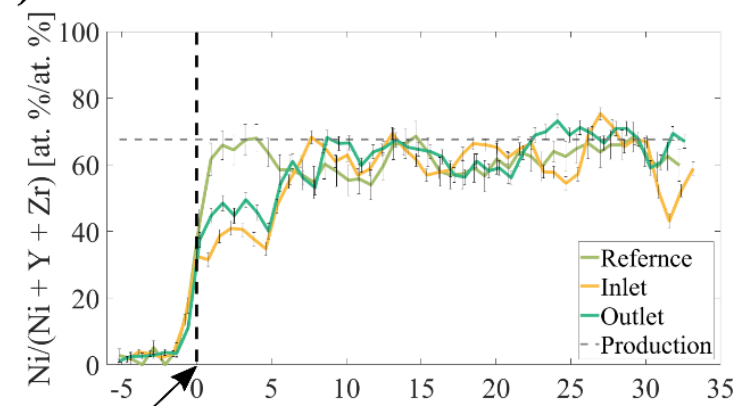

697 Figure 4: a) $\mathrm{Ni} /(\mathrm{Zr}+\mathrm{Y})$ (atomic ratio) mean value in two regions of the fuel electrode: close to the electrode-electrolyte 698 interface (average of EDS results computed on $25 \times 3 \mu \mathrm{m}^{2}$ and $50 \times 3 \mu \mathrm{m}^{2}$ areas) and on a large area of the support. b) $699 \mathrm{Ni} /(\mathrm{Ni}+\mathrm{Y}+\mathrm{Zr}$ ) (atomic ration) as a function of the distance from the electrolyte (EDS data obtained from $25 \mathrm{x}$ (3 to 20) $\mu \mathrm{m}^{2}$ and $50 \mathrm{x}$ (3 to 10) $\mu \mathrm{m}^{2}$ areas), the theoretical atomic ratio from the production is $\sim 67 \%$ and it is illustrated by a dashed gray line. The results are shown for the three sample analyzed in this study: reference, inlet and outlet. 

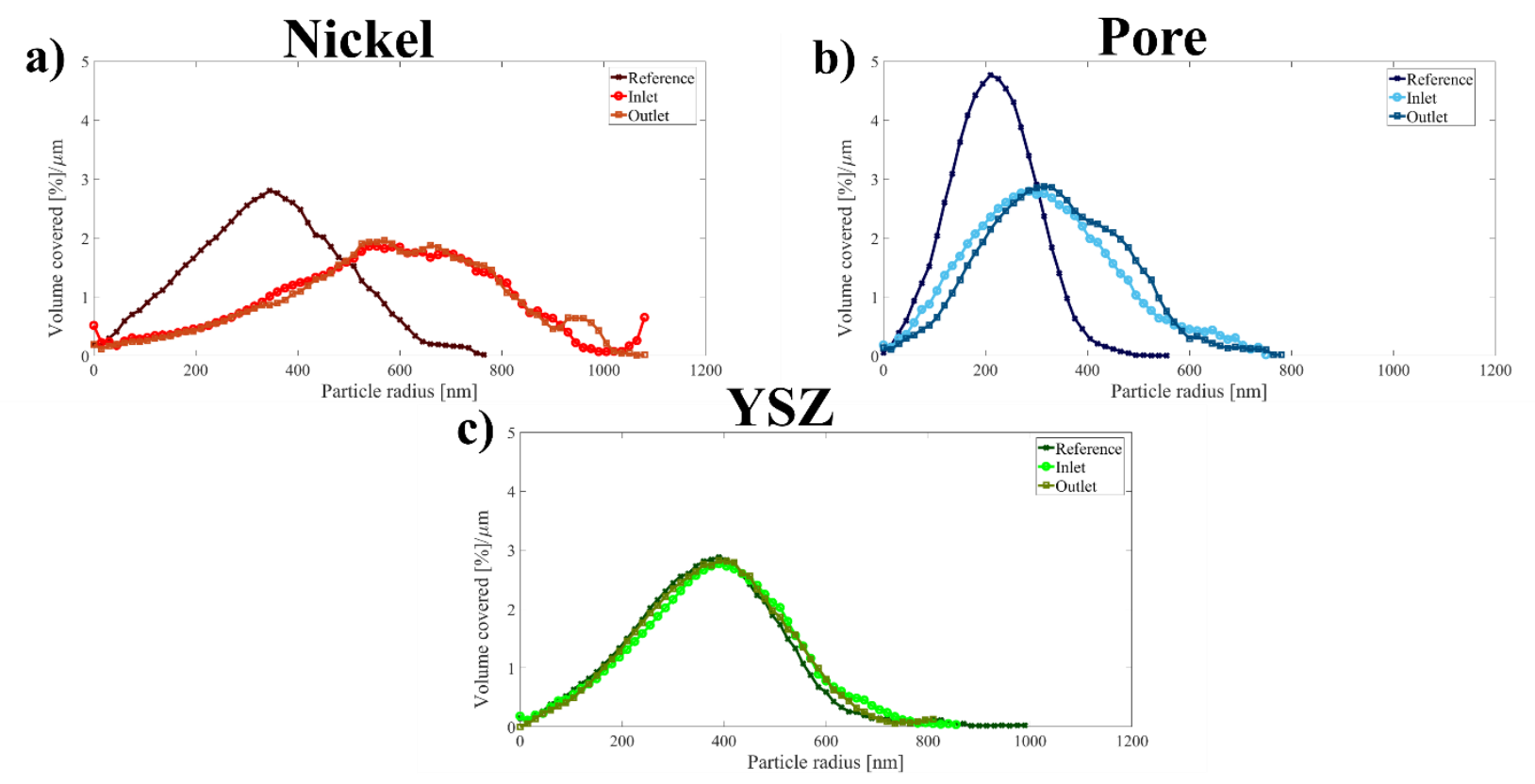

c)

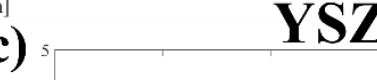

714 Figure 5: Continuous particles size distribution computed on the three volumes analyzed, each line in the graphs refers to one of the three samples analyzed: reference cell and aged cell at the inlet and the outlet side. Graph a) shows Ni 


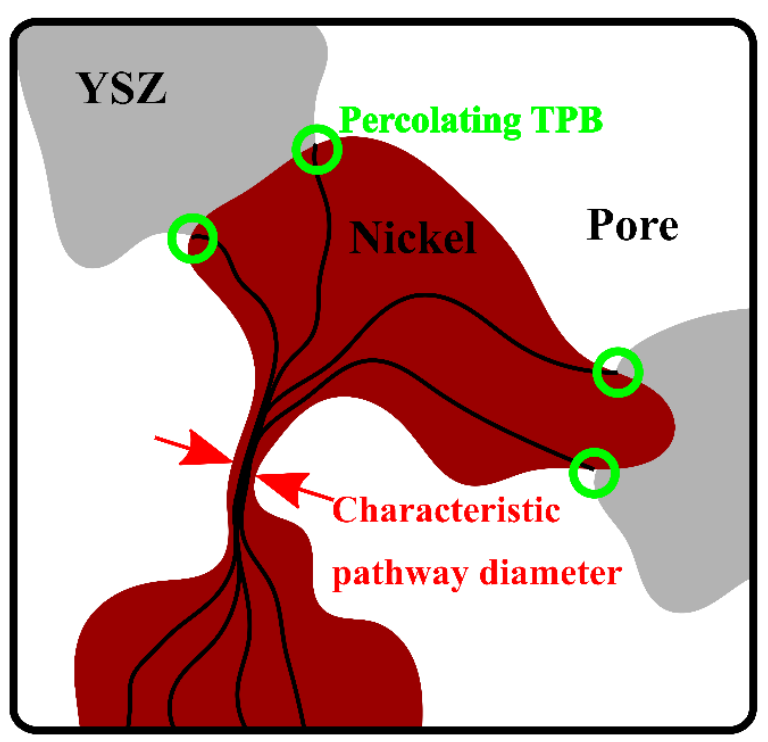

727 Figure 6: Sketch of characteristic pathway diameter concept. In the drawing, red arrows highlight the characteristic pathway for the Ni phase, and percolating TPB between Ni (red), YSZ (gray) and pore (transparent) are circled in green. 

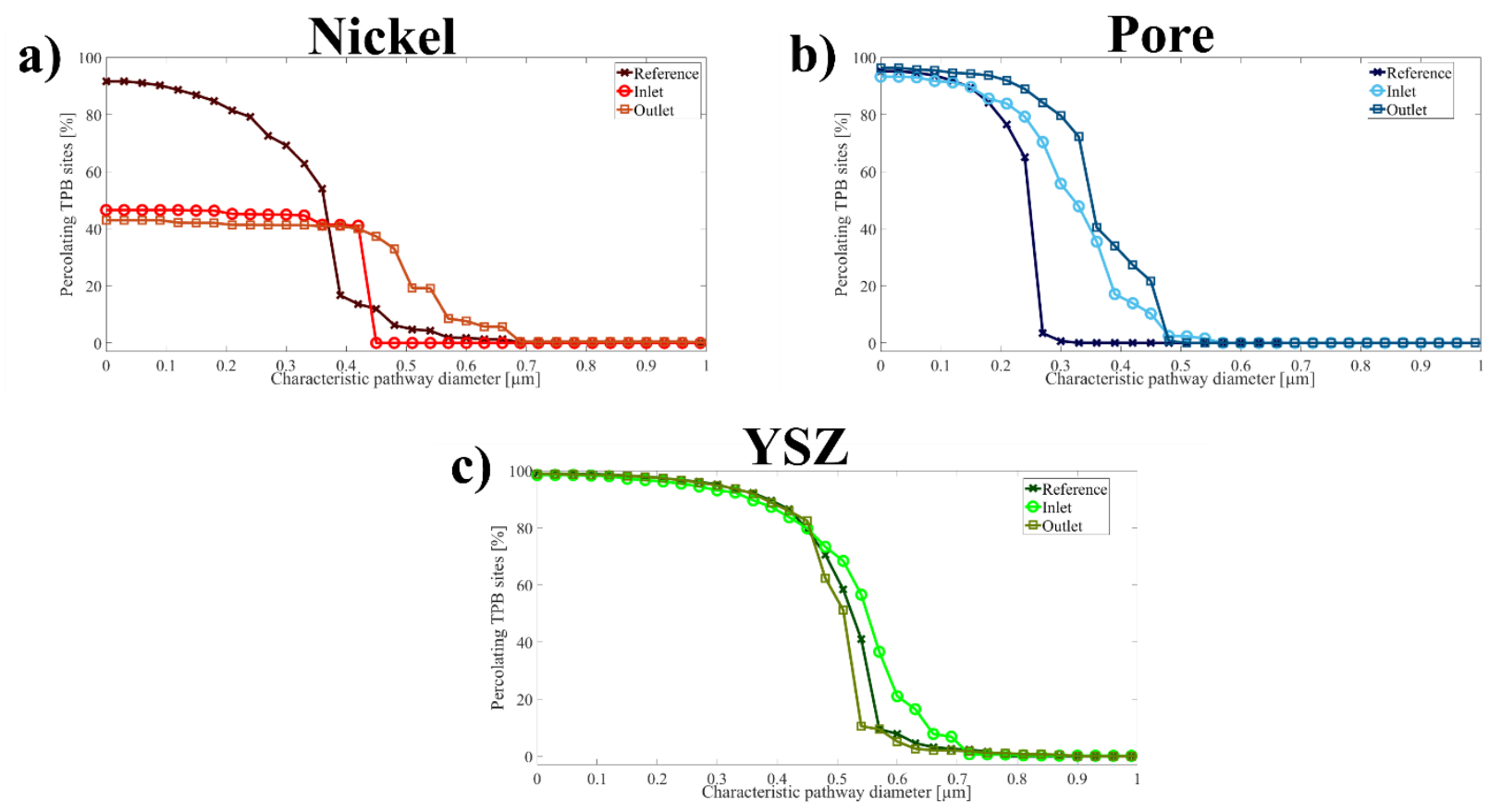

741 Figure 7: Characteristic pathway diameter calculated for each of the three phases of the electrode: a) Ni, b) Pore and c) 742 YSZ. The three lines in each graph represent the reference cell and the tested one at the inlet and the outlet side, respectively. 